\title{
Leading system transformation: A work in progress
}

\author{
Gregory B Whitby AM \\ Catholic Education Diocese of Parramatta
}

\author{
Maura Manning \\ Catholic Education Diocese of Parramatta
}

Dr Gavin Hays

Catholic Education Diocese of Parramatta

https://doi.org/10.37517/978-1-74286-638-3_11

\begin{abstract}
Gregory Whitby is a Fellow of the Australian Council of Educational Leaders, a Fellow of the Australian College of Education, a Fellow of Western Sydney University and Adjunct Professor at the Universal Business School Sydney. Greg's mission to transform schooling for every child and young person is driven by a strong commitment to justice and equity. He continues to challenge accepted thinking about learning and teaching for the change education can bring for all of us. Greg has been awarded an Order of Australia (AM) and a Papal Knighthood in the Order of St. Gregory the Great.
\end{abstract}

Maura Manning is the Director Learning at Catholic Education Diocese of Parramatta. She is a nationally accredited teacher who has held leadership roles in the independent and Catholic education sectors. Her research interests include leading innovative learning design and creative teaching practice.

Dr Gavin Hays supports school teams as they navigate change in implementing contemporary learning pedagogies and inspecting their impact. This work focuses on implementing and sustaining pedagogical change in the areas of inquiry learning, project- and problem-based learning, flipped learning, retrieval practice and science, technology, engineering and mathematics (STEM). In 2019, he completed his doctoral study on developing a new measure for conceptual knowledge under Professor Dr Henk Schmidt at Erasmus University, Rotterdam, the Netherlands.

\section{Abstract}

Internationally, the COVID-19 pandemic has profoundly disrupted the education sector. While NSW has avoided the longer periods of remote learning that our colleagues in Victoria and other countries have experienced, we have nonetheless been provoked to reflect on the nature of schooling and the systemic support we provide to transform the learning of each student and enrich the professional lives of staff within our Catholic learning community. At Catholic Education Diocese of Parramatta (CEDP), a key pillar of our approach is to create conditions that enable everyone to be a leader. Following the initial lockdown period in 2020 when students learned remotely, we undertook an informal teacher voice piece with the purpose of engaging teachers and leaders from across our 80 schools in Greater Western Sydney to reflect on and capture key learnings. This project revealed teachers and leaders reported very high feelings of self-efficacy, motivation and confidence in their capacity to learn and lead in the volatile pandemic landscape. These findings raised the question: how do we enable this self-efficacy, motivation and confidence in an ongoing way? This paper documents the systematic reflection process undertaken by CEDP to understand the enabling conditions a system can provide to activate everyone to be a leader in the post-pandemic future and the key learnings emerging from this process. 


\section{Introduction}

The call for educational transformation is echoing throughout the world as we approach our postpandemic future. In Australia, reviews of curriculum offerings are underway at both state and national levels as well as an examination of the pathways through education and how the outcomes of these diverse pathways are documented in a meaningful way. While CEDP has felt the fierce urgency of this call well before the pandemic, the rapid change that occurred throughout 2020 has accelerated this work. Societal change in this past year has been undeniable and further changes to the economy and employment patterns will emerge. The nature of teachers' work changed dramatically when lessons moved online last year and this opened possibilities for collaboration that had not previously been explored. Prior to the pandemic there were already concerns about teacher workloads and this has been further explored in recent papers (Gallop, 2021). As the staffing concerns that have cast an ominous shadow in our schools in recent years are coming to an outright crisis, we need to consider new ways of working and reflect on the use of systemic resources to support the transformation of teachers' work and students' learning.

Traditionally, as a system of Catholic schools, CEDP operates within a theory of action that sees some finite resources and expertise held at the centre and shared across schools to build the capacity of school leaders and teachers to bring about high-quality learning experiences for students at the local school level. During the volatile periods of 2020, principals observed leadership emerging from all aspects of their staff and high degrees of collaboration as teachers responded to rapid change. During this highly dynamic period, the Executive Director observed powerful leadership emerging at the local community level as the principals responded to their unique communities rather than trying to implement a 'one-size-fits-all' centrally managed model. This unique pandemic situation challenged the traditional structures and processes that have defined the system.

This challenge presented an ideal opportunity to reflect on our existing theory of action and the espoused strategic pillars of CEDP to determine the agility of our structures and processes in responding to changes and challenges.

Four priorities guide the work of our Catholic system:

- mission is countercultural

- learning is owned by the learner

- equity is the norm

- everyone is a leader.

Informed by this mission and these overarching strategic priorities, there are three key priorities for the System Learning Team (SLT) who support learning and teaching in schools by working with teachers in learning spaces, in partnership with school leadership teams and sometimes directly with students:

- expand a culture of innovation

- personalise learning for leaders

- champion diversity and equity.

The SLT operates within the following theory of action that connects the four actions and their intended influence or impact:

- teaching influences student learning

- teacher learning influences teaching

- school leadership influences teacher learning

- system leadership influences school leadership.

This paper documents a transparent and collaborative reflection on how the SLT supports schools to (in addressing the system intent) transform the learning of each student and enrich the professional lives of staff within our Catholic learning community. 


\section{Methodology}

The approach to this work was iterative and the process has been collaborative and transparent. We designed a three-phase structure referred to as the 'learning health check' that began with a quantitative survey delivered to all teaching and non-teaching staff in schools (including leaders) as well as the SLT. This was Phase 1. The aim of the quantitative survey was to assess the coherence of our resources and services provided in meeting the needs of our schools. It is envisaged that this instrument could be used as an annual measure of coherence. Phase 2 involves a more qualitative lens in further exploring the key themes identified in Phase 1 by assembling focus groups that will address some of the areas of misalignment to identify opportunities and recommendations that may not have been previously considered. The future opportunities identified in the focus groups will be categorised according to implementation suitability and timeframe. Finally, Phase 3 will utilise working parties across school and system learning to co-design and test prototype solutions of new ways of working. Figure 1 shows the components of each phase.

Figure 1 Three phase structure for the 'learning health check'

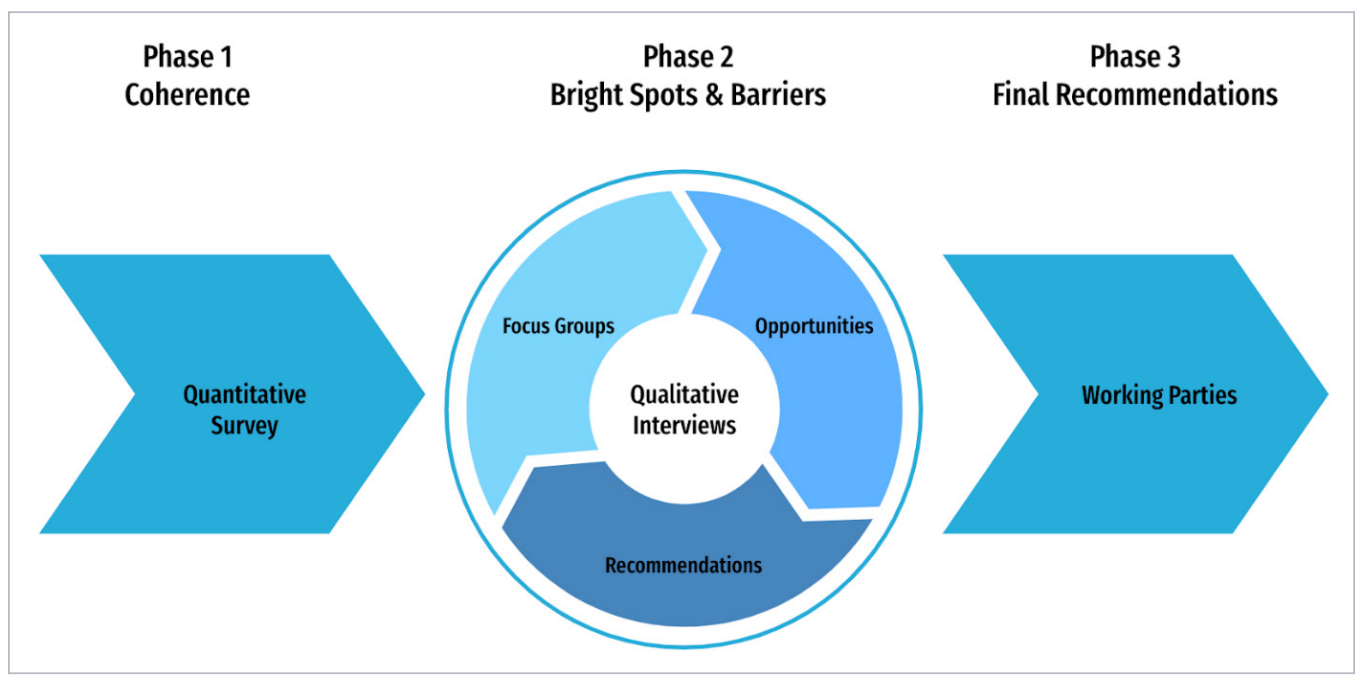

\section{Phase 1: Coherence}

A quantitative survey was constructed to evaluate the following two areas:

- Impact - learning strategic priorities including:

- impact on student learning (ISL)

- culture of innovation (Cl)

- personalised learning $(\mathrm{PL})$

- equity and diversity (ED)

- Process - learning theory of action

- student learning (SL)

- teaching $(\mathrm{TH})$

- teacher learning (TL)

- school leadership (SL)

- system leadership (SYL) 
The survey questions were designed to collect insights regarding the areas of impact and process across different roles and contexts within school-based personnel and SLT. Table 1 shows the questions that were used in the design of the qualitative survey.

The quantitative survey was administered in December 2020 and was distributed to both schoolbased personnel and SLT.

Table 1 Questions used to address the design of the qualitative survey

\begin{tabular}{|c|c|c|c|c|}
\hline & $\begin{array}{l}\text { Impact on student } \\
\text { learning (ISL) }\end{array}$ & $\begin{array}{l}\text { Culture of } \\
\text { innovation }(\mathrm{Cl})\end{array}$ & $\begin{array}{l}\text { Personalised } \\
\text { learning (PL) }\end{array}$ & $\begin{array}{l}\text { Equity and } \\
\text { diversity (ED) }\end{array}$ \\
\hline \multicolumn{5}{|c|}{ Question stem: The learning directorate: } \\
\hline \multirow[t]{2}{*}{$\begin{array}{l}\text { Student learning } \\
\text { (SL) }\end{array}$} & $\begin{array}{l}\text { 1.1 Supports me } \\
\text { to improve the } \\
\text { learning outcomes } \\
\text { of each student. }\end{array}$ & $\begin{array}{l}2.1 \text { Is open to new } \\
\text { ideas }\end{array}$ & $\begin{array}{l}3.1 \text { Provides choice } \\
\text { in how I solve } \\
\text { student learning } \\
\text { problems. }\end{array}$ & $\begin{array}{l}\text { 4.1 Provides access } \\
\text { to the resources } \\
\text { and services that } \\
\text { I need to improve } \\
\text { the learning } \\
\text { outcomes of each } \\
\text { student. }\end{array}$ \\
\hline & & $\begin{array}{l}\text { 2.2. Values the } \\
\text { contributions } \\
\text { and insights } \\
\text { of teachers to } \\
\text { improve student } \\
\text { learning outcomes } \\
\text { of each student. }\end{array}$ & & \\
\hline \multirow[t]{2}{*}{ Teaching (TH) } & $\begin{array}{l}\text { 1.2 Provides } \\
\text { support in } \\
\text { developing } \\
\text { teaching practices } \\
\text { that improve the } \\
\text { learning outcomes } \\
\text { of each student. }\end{array}$ & $\begin{array}{l}2.3 \text { Provides in } \\
\text { situ support that } \\
\text { enables me to } \\
\text { take ownership } \\
\text { over new teaching } \\
\text { practices that } \\
\text { improve the } \\
\text { learning outcomes } \\
\text { of each student. }\end{array}$ & $\begin{array}{l}3.2 \text { Provides } \\
\text { a range of in } \\
\text { situ learning } \\
\text { opportunities to } \\
\text { develop teaching } \\
\text { practice that are } \\
\text { personalised to my } \\
\text { needs. }\end{array}$ & $\begin{array}{l}4.2 \text { Listens and } \\
\text { understands my } \\
\text { diverse needs. }\end{array}$ \\
\hline & & $\begin{array}{l}2.4 \text { provides } \\
\text { resources that } \\
\text { enable me to take } \\
\text { ownership over } \\
\text { new teaching } \\
\text { practices that } \\
\text { improve the } \\
\text { learning outcomes } \\
\text { of each student. }\end{array}$ & & $\begin{array}{l}4.3 \text { is collaborative } \\
\text { in sourcing } \\
\text { appropriate } \\
\text { support and } \\
\text { resources to } \\
\text { improve the } \\
\text { learning outcomes } \\
\text { of each student. }\end{array}$ \\
\hline \multirow[t]{2}{*}{$\begin{array}{l}\text { Teacher Learning } \\
\text { (TL) }\end{array}$} & $\begin{array}{l}1.3 \text { provides } \\
\text { professional } \\
\text { learning } \\
\text { opportunities } \\
\text { that assist me } \\
\text { to transform the } \\
\text { learning of each } \\
\text { student. }\end{array}$ & $\begin{array}{l}2.5 \text { provides } \\
\text { me with new } \\
\text { knowledge and } \\
\text { skills that enrich } \\
\text { my professional } \\
\text { life. }\end{array}$ & $\begin{array}{l}3.3 \text { helps identify } \\
\text { learning and } \\
\text { teaching needs } \\
\text { within my school. }\end{array}$ & $\begin{array}{l}4.4 \text { is responsive } \\
\text { to school needs } \\
\text { in the resource } \\
\text { and service } \\
\text { allocation to build } \\
\text { the capacity of all } \\
\text { teachers. }\end{array}$ \\
\hline & & & $\begin{array}{l}3.4 \text { provides } \\
\text { support to address } \\
\text { these needs with } \\
\text { fair, constructive } \\
\text { feedback on my } \\
\text { work. }\end{array}$ & \\
\hline
\end{tabular}




\begin{tabular}{|c|c|c|c|c|}
\hline & $\begin{array}{l}\text { Impact on student } \\
\text { learning (ISL) }\end{array}$ & $\begin{array}{l}\text { Culture of } \\
\text { innovation }(\mathrm{Cl})\end{array}$ & $\begin{array}{l}\text { Personalised } \\
\text { learning (PL) }\end{array}$ & $\begin{array}{l}\text { Equity and } \\
\text { diversity (ED) }\end{array}$ \\
\hline $\begin{array}{l}\text { School Leadership } \\
\text { (SL) }\end{array}$ & $\begin{array}{l}1.4 \text { encourages } \\
\text { school leaders } \\
\text { to work } \\
\text { collaboratively to } \\
\text { lead the learning } \\
\text { agenda within their } \\
\text { school context } \\
\text { to transform the } \\
\text { learning of each } \\
\text { student. }\end{array}$ & $\begin{array}{l}2.6 \text { introduces } \\
\text { innovative ideas } \\
\text { into work practices } \\
\text { that enrich the } \\
\text { professional lives } \\
\text { of staff. }\end{array}$ & $\begin{array}{l}3.5 \text { provides } \\
\text { personalised } \\
\text { opportunities } \\
\text { for leaders to } \\
\text { transform the } \\
\text { learning of each } \\
\text { student. }\end{array}$ & $\begin{array}{l}4.5 \text { provides } \\
\text { autonomy in the } \\
\text { management } \\
\text { of the resources } \\
\text { and services that } \\
\text { schools access } \\
\text { to transform the } \\
\text { learning of each } \\
\text { student. }\end{array}$ \\
\hline \multirow[t]{2}{*}{$\begin{array}{l}\text { System Leadership } \\
\text { (SYL) The learning } \\
\text { directorate: }\end{array}$} & $\begin{array}{l}1.5 \text { works in } \\
\text { partnership with } \\
\text { schools to provide } \\
\text { mutual support } \\
\text { that identifies, } \\
\text { understands } \\
\text { and scales } \\
\text { improvement } \\
\text { efforts that } \\
\text { transform the } \\
\text { learning of each } \\
\text { student. }\end{array}$ & $\begin{array}{l}2.7 \text { champions } \\
\text { innovation by } \\
\text { seeking out new } \\
\text { strategies or } \\
\text { instruments that } \\
\text { support schools } \\
\text { to transform the } \\
\text { learning of each } \\
\text { student. }\end{array}$ & $\begin{array}{l}3.6 \text { facilitates } \\
\text { diverse } \\
\text { professional } \\
\text { learning } \\
\text { opportunities } \\
\text { that enrich the } \\
\text { professional lives } \\
\text { of staff. }\end{array}$ & $\begin{array}{l}4.6 \text { promotes } \\
\text { opportunities for } \\
\text { joint decision- } \\
\text { making in the } \\
\text { allocation of } \\
\text { resources and } \\
\text { services with each } \\
\text { school context. }\end{array}$ \\
\hline & $\begin{array}{l}1.6 \text { works in } \\
\text { partnership with } \\
\text { schools to provide } \\
\text { an appropriate } \\
\text { level of challenge } \\
\text { that identifies } \\
\text { improvement } \\
\text { efforts that } \\
\text { transform the } \\
\text { learning of each } \\
\text { student. }\end{array}$ & $\begin{array}{l}2.8 \text { champions } \\
\text { innovation } \\
\text { by seeking } \\
\text { out learning } \\
\text { frameworks that } \\
\text { support schools } \\
\text { to transform the } \\
\text { learning of each } \\
\text { student. }\end{array}$ & $\begin{array}{l}3.7 \text { supports } \\
\text { diverse } \\
\text { professional } \\
\text { learning } \\
\text { opportunities } \\
\text { that enrich the } \\
\text { professional lives } \\
\text { of staff }\end{array}$ & $\begin{array}{l}4.7 \text { promotes } \\
\text { opportunities for } \\
\text { divergent opinions } \\
\text { in the allocation } \\
\text { of resources and } \\
\text { services with each } \\
\text { school context. }\end{array}$ \\
\hline
\end{tabular}

\section{Phase 1 response rates}

Figures 2 shows the survey response rate of the total 971 school-based personnel responses. And Figure 3 shows the survey response rate of the total 70 system-based personnel responses. Descriptive statistics were calculated to identify any significant differences between the identified subgroups. Some of which included school type (primary and secondary), school population, leadership role (senior and other leader) and system team roles. Within the survey construction, qualitative responses were also collected and coded using Nvivo to identify possible themes for further investigation in Phase 2. In March 2021, a summary of findings was presented to system leaders and they were given the opportunity to engage their school-based personnel in an opportunity to ask clarifying and probing questions related to the findings. This process again was an opportunity to continually build relational trust within the system and an opportunity to coconstruct next steps. 
Figure 2 Survey response rate for school-based personnel responses

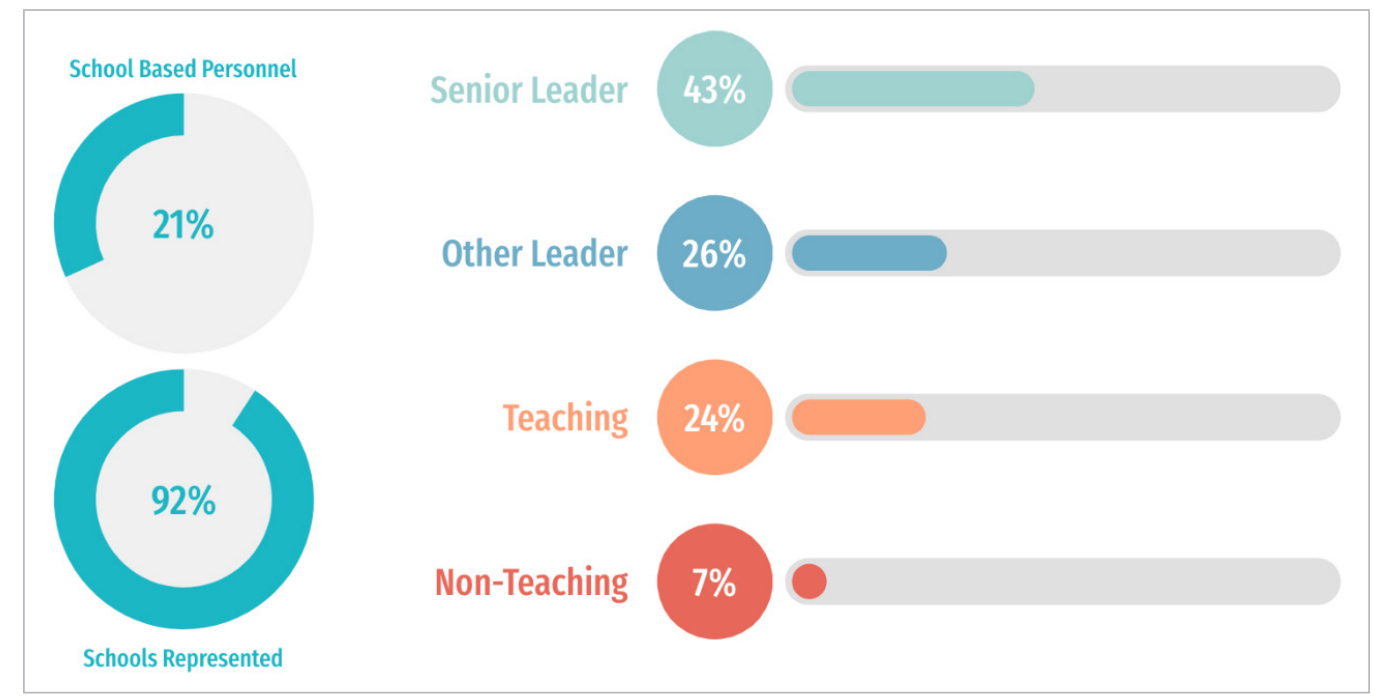

Figure 3 Survey response rate for SLT responses

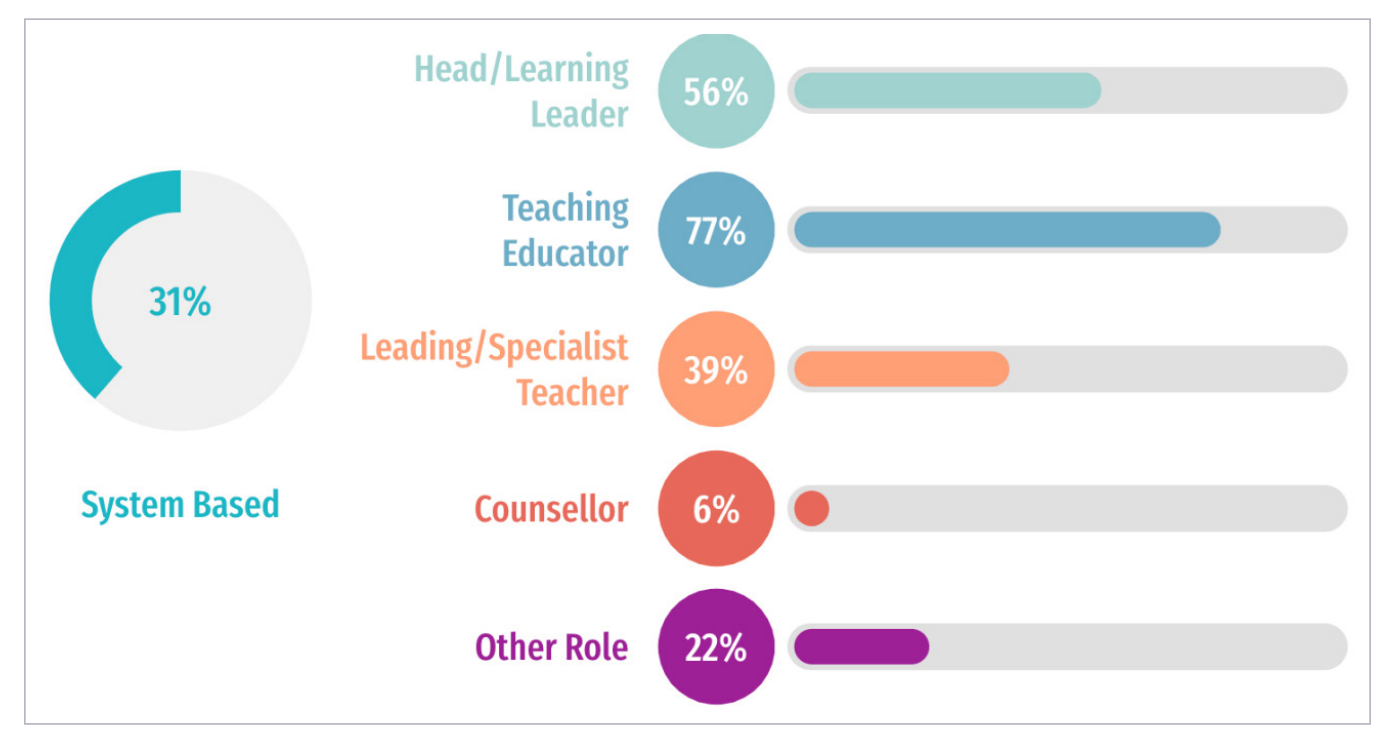

Priority areas

From the survey in Phase 1, we identified three priority areas that merited further investigation or attention due to the lower ratings or the discrepancies between school-based personnel and SLT responses.

- Priority 1 Alignment and trust between SLT and schools to enable leadership in all.

- Priority 2 Importance of structures and processes to support diversity and equity.

- Priority 3 Ensuring structures and processes foster innovation and transformation.

This paper focuses on Priority 1. 


\section{Priority 1 Alignment and trust between SLT and schools to enable leadership in all}

The quantitative data identified a pattern around the misalignment of perceptions between SLT and school-based personnel. SLT staff reported higher perceptions of their effect than school-based personnel. The qualitative comments flagged some concerns around the collaborations between the system office and schools. The responses suggest there may be weak relational trust between the system office and schools in some instances.

Some qualitative responses suggested some respondents did not share a belief in the Catholic systemic principle of making better use of finite resources by sharing expertise across schools. However, the feedback also suggested that when learning or other services are personalised or tailored to the context, respondents were most positive. It was apparent that when respondents felt their context was deeply understood by system office-based staff they felt their interactions were more positive.

This customised service is linked to respondents' desire to have genuine agency in all that they do. Respondents suggested that 'one-size-fits-all' approaches and policies or programs that eroded schools' capacity to make decisions based on their contexts left them feeling frustrated. Some respondents reported feeling constrained by the perception that system office personnel sometimes imposed a single way of doing things on schools without listening or understanding the context. There was a perception that the system office staff had 'an agenda' for their work that was not always in keeping with what the school believed was their priority.

We sought to explore how to build greater coherence and overall collective efficacy (Donohoo et al., 2018) as a learning system to activate all members of the community to transform the learning of each student and enrich the professional lives of staff through a series of focus groups with teachers, leaders and office-based staff.

\section{Phase 2: Bright spots and barriers}

The key insights from the quantitative data and the coding of the qualitative responses were grouped to focus on three priority areas. These were further explored through a series of targeted focus groups that invited participants to imagine possibilities for the future and ultimately engage colleagues in a co-design and testing of prototype solutions. The facilitation of the focus group meetings utilised a 'step in, step out and step back' protocol to enable participants the opportunity to identify bright spots in the way we currently work that make a difference in their role or context. But also, to explore the barriers or areas of possible misalignment. This protocol required participants to analyse the impact locally and broadly across the system to schools to ideate possible prototype solutions that could be deepened in Phase 3 . Phase 3 is currently being undertaken at the time of writing this paper.. 


\section{Conclusions}

While this remains a work in progress at the time of submission of this paper, some key themes have emerged through the focus group ideation process that will inform the future processes and structures of our system.

1. The constant transparent process of building trust with stakeholders through co-construction and collaborative unpacking is essential. Often at a system level,we expedite processes to get to outcomes.

2. System structures established to support improvement are not the same structures that support innovation and transformation.

3. A linear theory of action suggests knowledge, expertise and power is held by 'authority figures', which may contribute to erosion of empowerment, creativity and learning of teachers.

4. System structures must enable ideas and expertise to emerge from any part of the organisation to enable anyone to be a leader.

5. An implementation stance erodes teacher agency and learning capacity.

6. The complexity of needs in classrooms demand new ways of working and new solutions.

7. Teacher learning must be central to a teacher's day, not an add-on.

8. Horizontal connections between schools enable teachers to build system knowledge and contribute new understandings to the system discourse.

Following this idea generation phase, we will move to identifying the best possible solutions. Different stakeholder groups will be invited to engage with these ideas and participate in the discernment process. Through this process, we will seek to identify potential 'prototypes' that can be trialled and evaluated to inform our processes and structures in our post-pandemic future.

\section{References}

Donohoo, J., Hattie, J. \& Eells, R. (2018). The power of collective Efficacy. Educational Leadership, 75(6), 40-44.

Gallop, G., Kavanagh, T. \& Lee, P. (2021). Valuing the teaching profession: An independent inquiry. NSW Teachers Federation. https://www.nswtf.org.au/pages/reports 